\title{
California black rails depend on irrigation-fed wetlands in the Sierra Nevada foothills
}

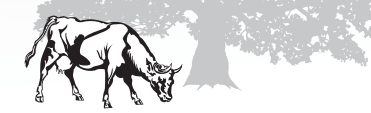

by Orien M.W. Richmond, Stephanie K. Chen, Benjamin B. Risk, Jerry Tecklin and Steven R. Beissinger

\section{After California black rails were} discovered at the UC Sierra Foothill Research and Extension Center in 1994, an extensive population of this rare, secretive marsh bird was found inhabiting palustrine emergent persistent (PEM1) wetlands throughout the northern Sierra Nevada foothills. We inventoried a variety of PEM1 wetlands to determine which habitats would likely support black rails. Black rails were positively associated with larger PEM1 wetlands that had flowing water, dense vegetation and irrigation water as a primary source; they were negatively associated with fringe wetlands and seasonal water regimes. Recommendations for managing black rail habitat in the northern Sierra foothills include prioritizing the conservation of PEM1 wetlands with permanently or semipermanently flooded water regimes and shallow water zones (less than 1.2 inches), especially those that are greater than 0.25 acres in size; avoiding wetland vegetation removal or overgrazing, especially during the black rail breeding season (approximately March through July); maintaining and improving wetland connectivity; ensuring that impacts to black rails are considered in the environmental review process for development projects; and integrating management guidelines for black rails into existing wetland conservation programs.

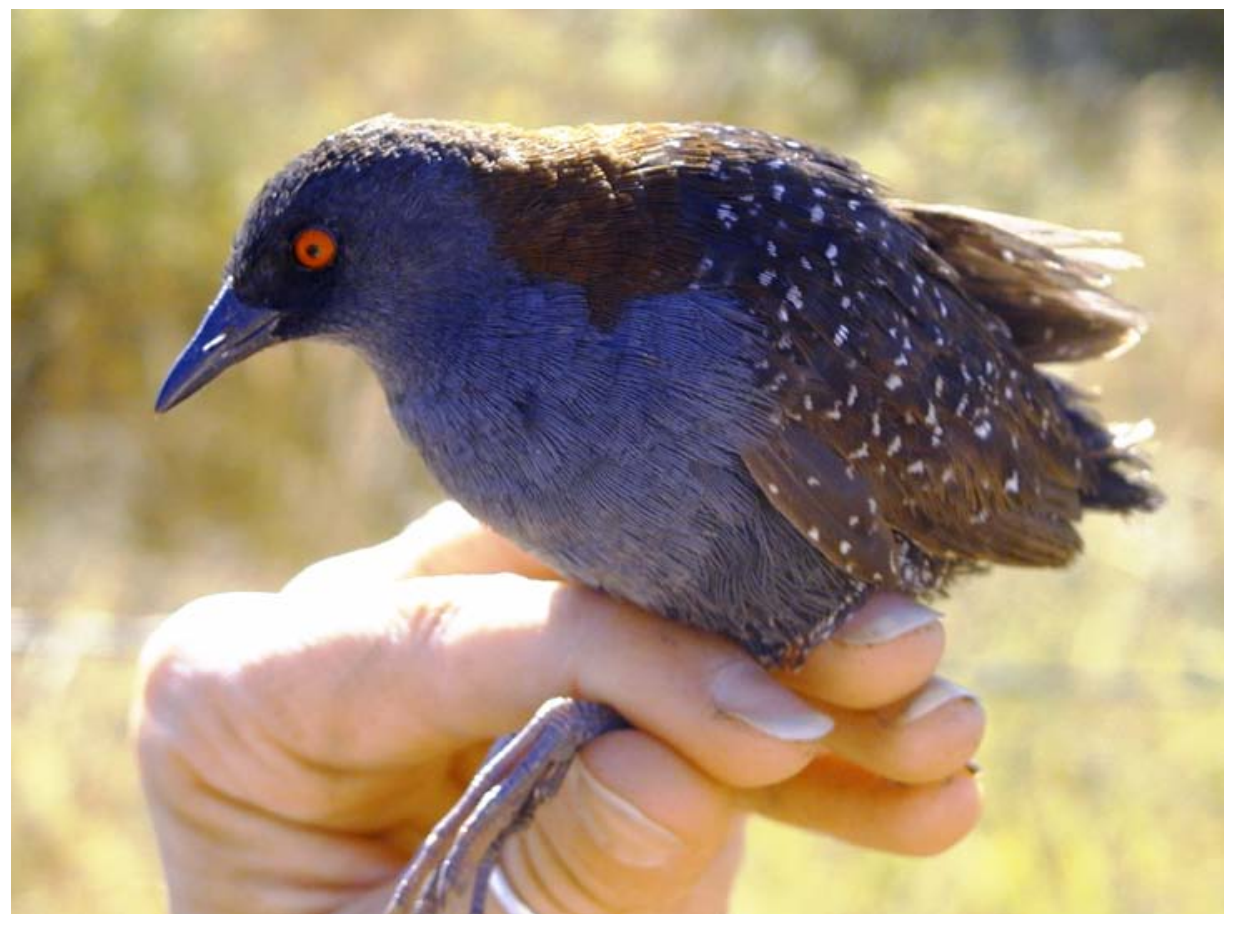

Over the past decade, the threatened, secretive California black rail has been found at more than 160 wetlands in the Sierra Nevada foothills.

$\mathrm{T}$ he rare, secretive California black rail depends on emergent wetland habitats for all stages of its life cycle. It is the smallest rail in North America and has a patchy and poorly understood distribution. In western North America, it is found in saltwater, brackish and freshwater marshes along the Pacific coast from Bodega Bay to northwest Baja California, in the the San Francisco Bay-Delta Estuary (where it is most abundant), inland in small numbers in the Salton Trough and along the lower Colorado River, and in the northern Sierra foothills of Butte, Nevada, Placer and Yuba counties, where it was recently discovered (Aigner et al. 1995; Conway and Sulzman 2007; Eddleman et al. 1994; Evens et al. 1991; Richmond et al. 2008).

After California black rails (Laterallus jamaicensis coturniculus) were discovered at the UC Sierra Foothill Research and Extension Center (SFREC) in 1994 (Aigner et al. 1995), an extensive search for this species - which is on California's list of threatened species (CDFG 2008) — was carried out throughout the Sacramento Valley and Sierra foothills. While information on the foothill population's distribution has been published (Richmond et al. 2008), a detailed description of the habitats occupied by black rails in the foothills is lacking.

\section{Study area and data collection}

Little information is available for the state's small $(<25$ acres $[<10$ hectares]), inland, palustrine emergent persistent (PEM1) wetlands (Cowardin et al. 1979). Also known as marshes or fens, PEM1 wetlands are nontidal and dominated by perennial, erect, rooted, herbaceous hydrophytes (plants able to grow in water or on a substrate that is at least periodically deficient in oxygen due to flooding, excluding mosses and lichens) that normally remain standing from the end of one growing season until the beginning of the next (Cowardin et al. 1979).

We surveyed a network of 228 PEM1 wetlands spanning approximately 400 square miles (1,036 square kilometers) in Butte, Nevada and Yuba counties in the 


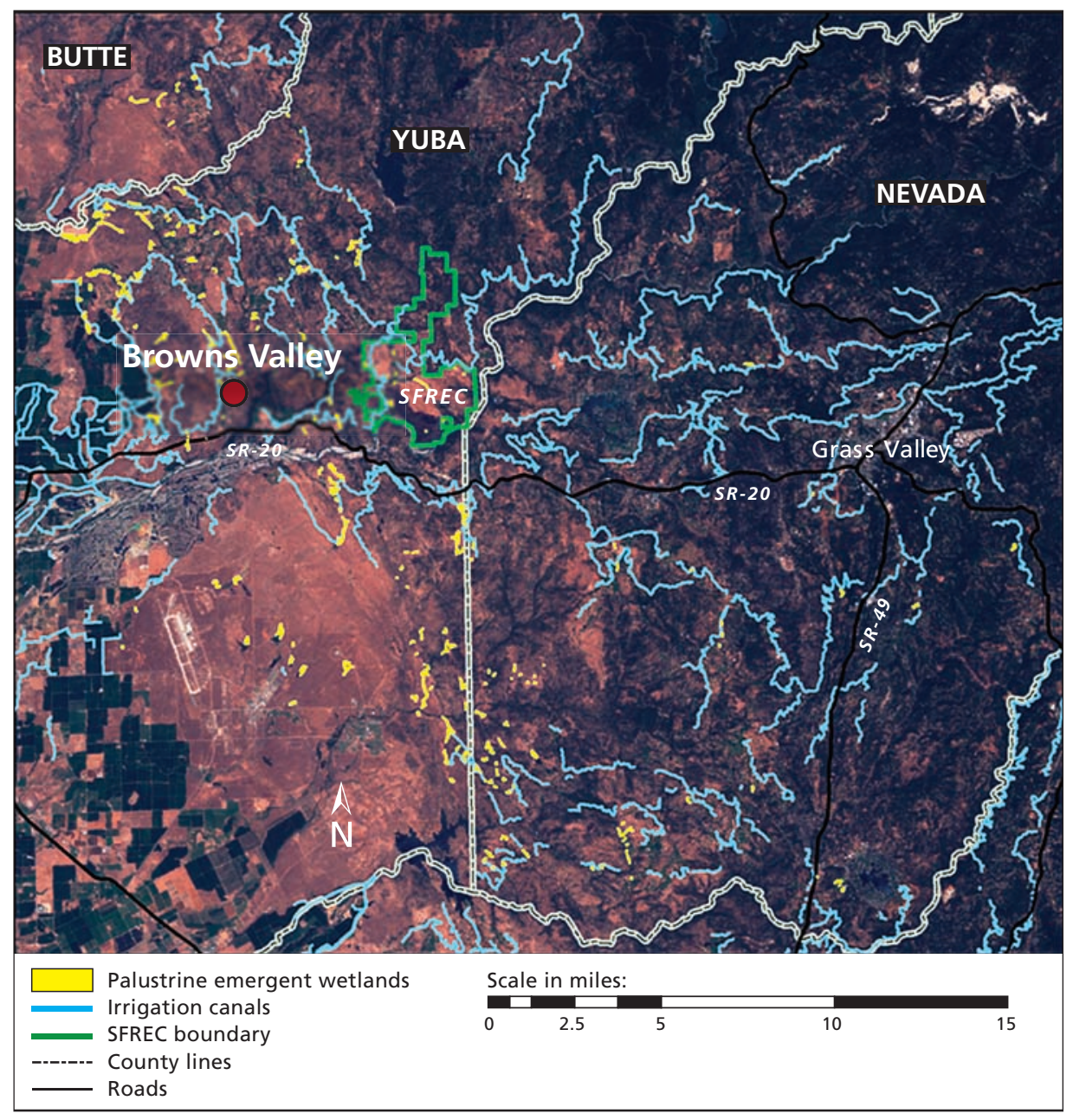

Fig 1. Distribution of surveyed palustrine emergent (PEM1) wetlands and irrigation canals in the northern Sierra Nevada foothills.

northern Sierra foothills, from 2002 to 2008 (fig. 1). The region's Mediterranean climate is characterized by hot, dry summers and cool, wet winters with an average annual precipitation of approximately 30 inches (76 centimeters), with approximately $90 \%$ falling between October and March (Lewis et al. 2000).

We identified candidate PEM1 wetlands in the foothills using U.S. Geological Survey (USGS) topographic quad maps, aerial photographs and U.S. Fish and Wildlife Service National Wetland Inventory maps; we also encountered many sites during field surveys.

We focused on wetlands from 50 to 3,000 feet in elevation with water regimes (temporal patterns of water flow) consistent with previous descriptions of rail habitat, including those that appeared to be permanently, semipermanently and seasonally flooded, intermittently exposed, and saturated. We also surveyed wetlands with water regimes that were less likely to support black rails, including ones that were temporarily and intermittently flooded (Cowardin et al. 1979).

Wetland mapping. We mapped all surveyed wetlands in the field using a backpack Trimble Pro XR GPS (global positioning system) receiver and TDC1 Asset Surveyor data collector. We delineated wetland boundaries by including all areas that appeared permanently or seasonally flooded with shallow water depths where hydrophytes composed more than $50 \%$ of the vegetation. We focused our mapping and analysis on vegetated wetland zones and excluded areas of open water, because black rails tats. We obtained geospatial data on irrigation canals from the USGS National Hydrography Dataset (http://nhd.usgs. gov/data.html). We attempted to survey all PEM1 wetlands identified in our study area, but were sometimes unable to access sites on private lands.

Habitat assessment. We conducted habitat assessments between June 1 and Aug. 31 from 2002 to 2008 and are not known to use open-water habi- recorded water source, geomorphic setting, evidence of a seasonal water regime, and hydrological conditions at each wetland. We visually determined the primary water source at each wetland as irrigation canal, rainfall, spring or stream. In some cases, flows or downslope seepage from irrigation canals augmented natural stream or spring flows. We considered a wetland to be primarily stream-fed if it was situated along a stream channel, and primarily spring-fed if it received most of its water from subsurface sources.

Hydrology. We assigned each wetland to one of four geomorphic setting categories: (1) slope wetlands formed by the discharge of water to the surface on sloping land, (2) depressional wetlands situated in local depressions with closed elevation contours, (3) fluvial wetlands situated along stream channels and (4) fringe wetlands bordering water bodies such as ponds, lakes or rice fields (see page 91). We recorded whether sites exhibited evidence of a seasonal water regime - indicating that they might become dry for at least a part of the year - by noting dried portions of sites, dead or stressed hydrophytic vegetation, encroachment of upland vegetation, or reduced water levels that exposed bare mud. We assessed the presence of flowing water, standing water, saturated mud and firm mud. A "wettest hydrology rating" was determined for each wetland according to the following sequence: flowing water, standing water, saturated mud, firm mud and dry. For example, a wetland that had standing water, saturated mud and firm mud present would have a wettest hydrology rating of standing water.

To examine relationships between annual rainfall and wetland hydrological characteristics, we obtained precipitation data from California Irrigation Management Information System (CIMIS) station 84 in Browns Valley, Calif., which was situated in the central part of the study area (www. cimis.water.ca.gov).

Plant species. We collected data on plant species diversity in 2007 at a subset of 20 PEM1 wetlands ranging in size from 0.7 to 3.2 acres (0.3 to 1.3 hectares). Within each wetland we surveyed four randomly placed 10.9-yard (10-meter) transects and identified all plants to 
genus or species that touched a vertical pole held at ten 3.3-foot (1-meter) intervals along each transect.

We collected additional hydrological and vegetative data at randomly sampled points at a subset of 184 PEM1 wetlands in 2008. We generated 10 random points within wetland boundaries for sites greater than 0.62 acre $(0.25$ hectare), eight points for sites from 0.25 to 0.62 acre ( 0.1 to 0.25 hectare) and five points for sites less than 0.25 acre (0.1 hectare). At each point, we recorded the hydrology/substrate (flowing water, standing water, saturated mud, firm mud, dry wetland), water depth and dominant vegetation using nine broad vegetation groups: cattails (Typhaceae), cutgrass (Leersia oryzoides), forbs, hardstem bulrush (Scirpus acutus), Himalayan blackberry (Rubus discolor), other grasses (Poaceae), other sedges (Cyperaceae), rushes (Juncaceae) and willows (Salix spp.). At each point we also measured vegetation density (or cover) in six height strata by recording whether or not any vegetation touched a vertically held 3.9-foot (1.2-meter) pole (vegetation present or absent). We estimated vegetation heights using the midpoint of the tallest height strata with vegetation present at each point.

Call-playback surveys. Concurrent with the habitat assessments, we conducted call-playback surveys between June 1 and Aug. 31 from 2002 to 2008, to determine black rail occupancy. We played recorded rail vocalizations at stations spaced 44 to 55 yards (40 to 50 meters) apart at each wetland (details in Richmond et al. 2008). Sites were visited up to five times in 2002 and up to three times from 2003 to 2008 using a removal design: in each year, we did not revisit a site after we detected black rails. The average probability of detecting occupancy at a site after multiple visits (three or five) was extremely high (0.99) from 2002 to 2006 (Richmond et al. 2008).

All statistical analyses were performed using Program R (R Development Core Team 2008). Unless otherwise noted, we report means \pm S.E.

\section{Distribution of PEM1 wetlands}

PEM1 wetlands in the northern Sierra foothills were generally small (less than 25 acres [10 hectares]), patchy ecosystems surrounded by a matrix of mixed vegetation communities (oak woodland, annual grassland, riparian forest) and land uses (rangeland, agricultural, residential). Wetlands were distributed along the western edge of the northern Sierra Nevada foothills (fig. 1) and ranged from 79 to 2,582 feet (24 to 787 meters) above sea level, with a mean elevation of $545 \pm 30$ feet (166 \pm 9 meters). PEM1 wetlands averaged $2.62 \pm 0.25$ acres (1.06 \pm 0.10 hectares) in size, with a positive skew (median = 1.16 acres [0.47 hectare] range $=0.02$ to 23.2 acres [0.01 to 9.39 hectares]). Most
(89\%) PEM1 wetlands were located less than or equal to 547 yards (500 meters) from irrigation canals (fig. 1). Most (63\%) PEM1 wetlands were on private lands, while $37 \%$ were on public lands including Beale Air Force Base, Daugherty Hill Wildlife Area, SFREC and Spenceville Wildlife Area.

\section{Hydrological features}

Irrigation water was the most common water source for the PEM1 wetlands that were surveyed, with $68 \%$ of wetlands primarily fed by irrigation
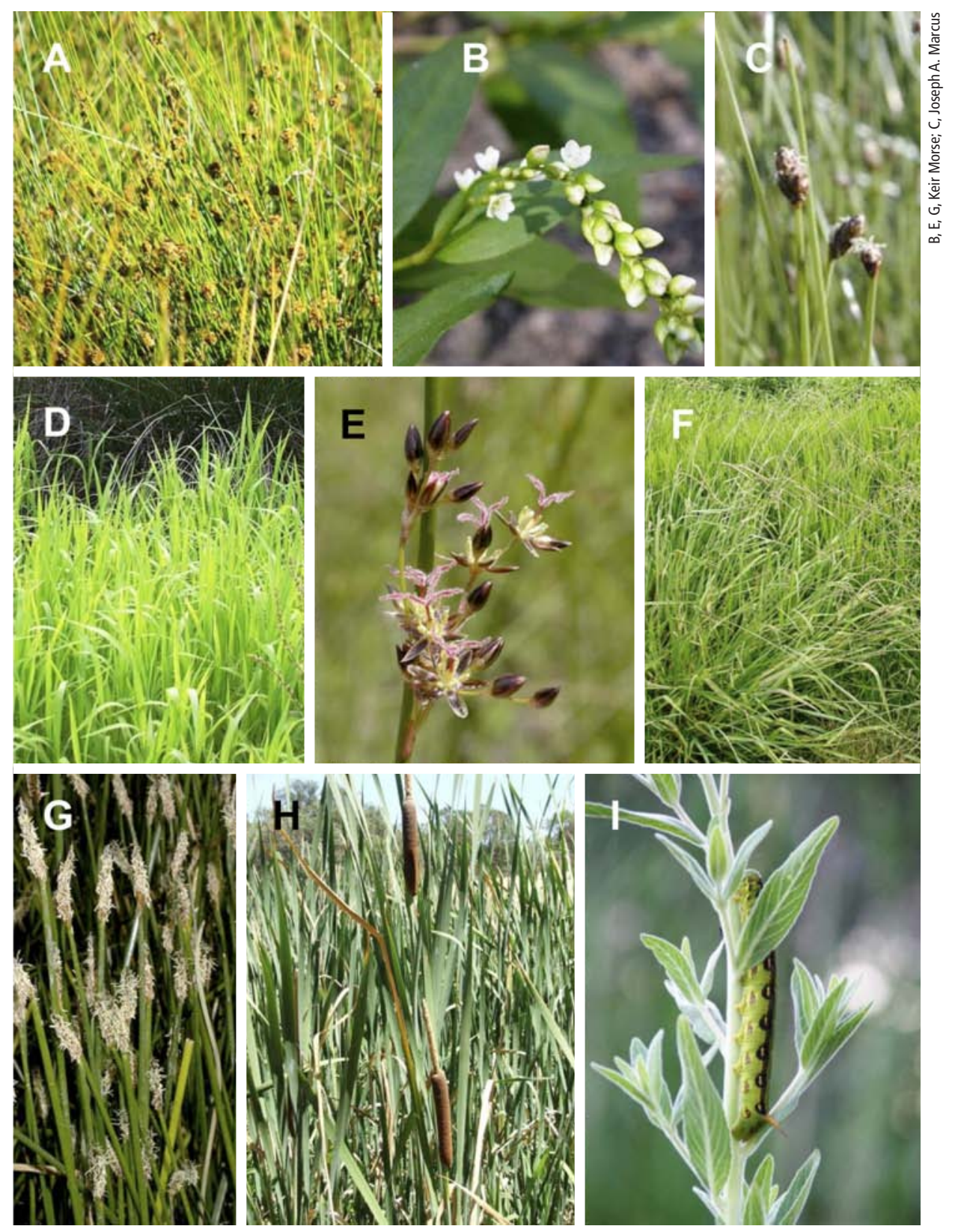

The nine most-common plant species found in 20 PEM1 wetlands in the northern Sierra foothills were (not in order of prevalence) (A) common rush, (B) water smartweed, (C) sand spikerush, (D) rice cutgrass, $(E)$ Baltic rush, $(F)$ dallis grass, $(G)$ common spikerush, $(H)$ cattail and $(\mathrm{I})$ willowherb. 


\begin{tabular}{|c|c|c|c|c|}
\hline \multirow[b]{2}{*}{ Wettest hydrology rating } & \multicolumn{2}{|c|}{ Wetter years: $2002-2006 t$} & \multicolumn{2}{|c|}{ Drier years: $2007-2008 \ddagger$} \\
\hline & $\begin{array}{l}\text { Irrigated } \\
(n=128)\end{array}$ & $\begin{array}{l}\text { Not irrigated } \\
(n=64)\end{array}$ & $\begin{array}{l}\text { Irrigated } \\
(n=134)\end{array}$ & $\begin{array}{l}\text { Not irrigated } \\
(n=68)\end{array}$ \\
\hline & \multicolumn{4}{|c|}{ 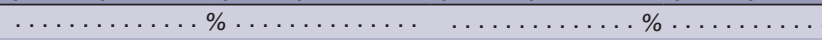 } \\
\hline Flowing water & 72 & 56 & 73 & 46 \\
\hline Standing water & 15 & 35 & 18 & 41 \\
\hline Saturated mud & 9 & 5 & 3 & 2 \\
\hline Firm mud & 1 & 0 & 3 & 3 \\
\hline Dry wetland & 4 & 3 & 3 & 7 \\
\hline
\end{tabular}

canals, $22 \%$ by springs, $6 \%$ by streams and $4 \%$ by rainfall. Irrigation water is collected from the Sierra snowpack, stored in reservoirs, transported through a network of canals and delivered to customers who use it mainly for flood irrigation of pastures for livestock grazing. Of the wetlands primarily fed by irrigation canals, we calculated that $84 \%$ were fed by deliberate irrigation and $16 \%$ by unintentional canal leaks.

The most common geomorphological setting for PEM1 wetlands was slope (47\%), followed by depressional (20\%), fluvial (19\%) and fringe (14\%). Fringe wetlands were typically located at lower elevations - closer to the valley floor — averaging 413 feet (126 meters) above sea level, while the other wetland types were found at higher elevations and averaged 564 feet (172 meters) above sea level.

Hydrological conditions in PEM1 wetlands differed significantly by water source. Most PEM1 wetlands $(66 \%)$ had a wettest hydrology rating of flowing water, 23\% standing water, $6 \%$ saturated mud, $1 \%$ firm mud and 4\% dry, averaged over the 2002 to 2008 study period. The percentage of wetlands with flowing water was higher at irrigated sites versus nonirrigated sites $\left(\chi^{2}=27.9, \mathrm{df}=4, P<0.001\right)$ (table 1). Surprisingly, the percentage of wetlands with flowing water did not differ significantly between wetter and drier years at both irrigated $\left(\chi^{2}=6.6, \mathrm{df}=4\right.$, $P=0.16)$ and nonirrigated $\left(\chi^{2}=5.2, \mathrm{df}=\right.$ $4, P=0.26)$ sites. Based on the random- point data collected in 2008, the percent surface area covered by the substrate/ hydrology classes in PEM1 wetlands averaged 5\% flowing surface water, $13 \%$ standing water, $16 \%$ firm mud, $20 \%$ saturated mud and $46 \%$ dry substrate. PEM1 wetlands were generally shallow, averaging $1.00 \pm 0.14$ inches $(2.55 \pm 0.35$ centimeters) in water depth, with a positive skew $($ median $=0.20$ inches $[0.50$ centimeter]; range $=0$ to 12.4 inches [0 to 31.5 centimeters]).

About $24 \%$ of PEM1 wetlands exhibited some evidence of a seasonal water regime between June and August 2008, which was a relatively dry year. Of these wetlands, about half had springs, streams and rainfall as primary water sources, and half had irrigation water as the primary source. These seasonal of habitats that varied both spatially and temporally.

\section{Plant diversity}

The PEM1 wetlands were floristically diverse, both between and within sites. We identified a total of 46 plant species across 20 sites in 2007 (table 2). The average number of plant species identified at each wetland was $10.1 \pm 0.8$ (range $=4$ to 19). The most frequent species were common rush (Juncus effusus) and cattails (Typha latifolia, T. angustifolia or T. domingensis, not distinguished in the field), which occurred at $38 \%$ and $35 \%$ of the points sampled, respectively. Four species, including dallis grass (Paspalum dilatatum), common spikerush wetlands created a shifting patchwork

Since black rails are listed as threatened by the California Department of Fish and Game, it is important to characterize their precise habitat requirements in this newly discovered part of their range.

(Eleocharis macrostachya), willowherb (Epilobium ciliatum) and rice cutgrass (Leersia oryzoides) each occurred at between $5 \%$ and $10 \%$ of the points sampled, while all other species occurred at less than $5 \%$ of the points sampled. All species identified in the Poaceae family were nonnative and invasive, except for rice cutgrass. This does not come as a surprise, given that California's grasslands are dominated by nonnative, invasive species.

A few unexpected species were present, such as large periwinkle (Vinca major), an invasive garden species, and wild grape (Vitis californica). Himalayan blackberry is a nonnative invasive plant and was observed to overgrow wetlands in some settings. The percentage of obligate wetland plants ranged from $40 \%$ to $95 \%$, facultative wetlands or plants from $0 \%$ to $60 \%$, and facultative obligate upland plants from $0 \%$ to $37 \%$ across all sites (USFWS 1988) (table 2). Based on the random-point data collected from 184 PEM1 wetlands in 2008, the percent coverage by broad vegetation classes was, on average, $26 \%$ grasses (excluding rice cutgrass), $24 \%$ rushes, $12 \%$ cattails, $12 \%$ sedges (excluding hardstem bulrush), $7 \%$ Himalayan blackberry, $6 \%$ forbs, 5\% hardstem bulrush, $3 \%$ willows and $1 \%$ rice cutgrass.

\section{Black rail use of PEM1 wetlands}

Black rails typically occur in the shallowest zones of wetland edges where water depths are generally less than 1.2 inches ( 3 centimeters) (Flores and Eddleman 1995). In the northern Sierra foothills, they are resident and occupy PEM1 wetlands year-round (Richmond et al. 2008). They construct well-concealed nests in dense vegetation over moist soil or very shallow water (Eddleman et al. 1994). The breeding season in the foothills is unknown but extends from approximately March through July in other California locations (Eddleman et al. 1994). The black rail's preferred wetland habitats have undergone severe historical declines in California due to habitat destruction for agriculture, salt production and urbanization (Eddleman et al. 1994). Since black rails are listed as threatened by the California Department of Fish and Game, it is important to characterize their precise habitat requirements in this 
newly discovered part of their range.

We found black rails at 158 PEM1 wetland sites during our surveys from 2002 to 2008 in the Sierra foothills.

Black rails had strong positive associations with larger PEM1 wetlands fed by irrigation water. PEM1 wetlands that had at least one black rail detection (mean area $3.2 \pm 0.2$ acres $[1.3 \pm 0.1$ hectares]; $n=158)$ were significantly larger ( $t$-test on log-transformed data; $P<0.001)$ than wetlands without black rails (mean area $1.2 \pm 0.2$ acres $[0.5 \pm 0.1$ hectare]; $n=70$ ) from 2002 to 2008 (fig. 2). The median size of wetlands with black rails was 1.63 acres (0.66 hectare) compared to 0.43 acre ( 0.18 hectare) for wetlands without black rails.
No significant differences were detected in elevation between wetlands with and without rails (fig. 2). The occurrence of black rails in PEM1 wetlands was significantly related to water source $\left(\chi^{2}=29.02, \mathrm{df}=3, P<0.001\right)$ (table 3$)$ and geomorphic setting $\left(\chi^{2}=9.15\right.$, $\mathrm{df}=3, P<0.05$ ) (table 3 ). These patterns were driven by the high occurrence of

TABLE 2. Plant species and occurance in 20 PEM1 wetlands of the northern Sierra foothills in 2007, and U.S. Fish and Wildlife Service (1988) wetland indicator category

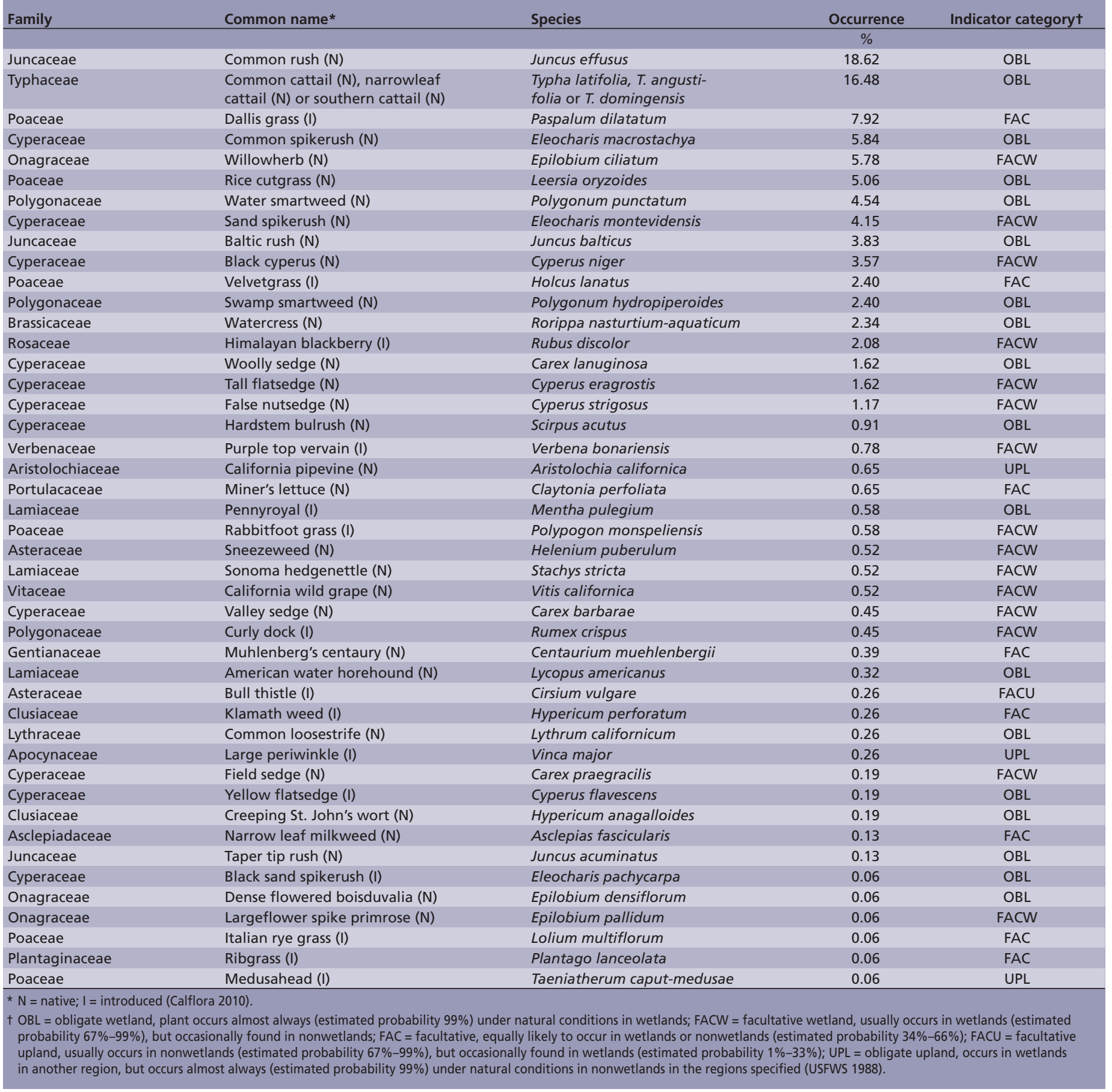




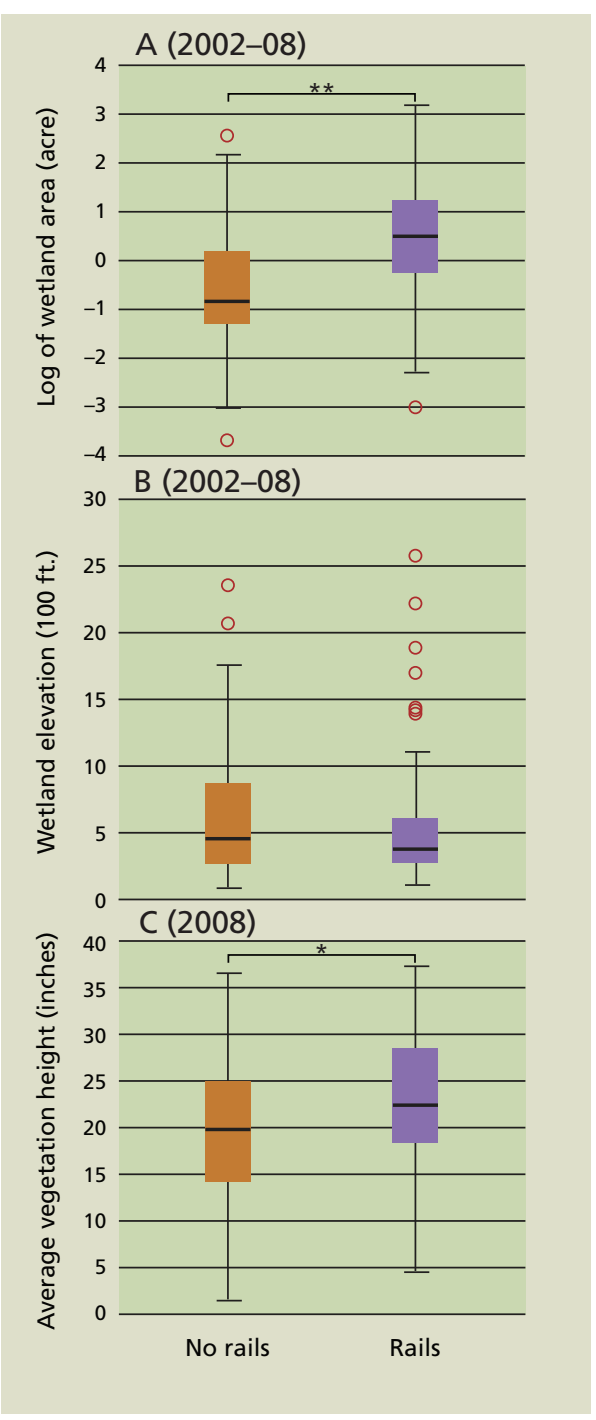

Fig. 2. Differences in area and elevation for wetlands in northern Sierra foothills that had at least one black rail present from 2002 to 2008 vs. wetlands without black rails in 2008 , and differences in vegetation height for wetlands with black rails vs. wetlands without black rails. Boxes depict lower and upper quartiles, bold lines depict medians, whiskers extend to the most extreme data point, which is no more than 1.5 times the interquartile range, and outliers are shown as open circles. * Significant difference, $t$-test, $P<0.01$; ** significant difference, $t$-test, $P<0.001$.

black rails in wetlands fed primarily by irrigation water and by the low occurrence of rails in wetlands fed primarily by rainfall and in fringe wetlands (table 3). Black rails rarely used livestock watering ponds (stock ponds) with narrow fringes of emergent vegetation and mostly deep (greater than 1 foot) water; however, seepage zones below bermed ponds often provided suitable shallowwater conditions.

Black rails were strongly, positively associated with flowing water and neg- atively associated with drier PEM1 wetlands and wetlands with evidence of a seasonal water regime. The occurrence of black rails in PEM1 wetlands was significantly related to the wettest hydrology rating $\left(\chi^{2}=153.30, \mathrm{df}=6, P<0.001\right)$ (table 4). This pattern was primarily driven by the high use of wetlands with flowing water, the low use of wetlands with standing water as the wettest hydrology rating, and the low use of dry wetlands (table 4). Black rail occupancy was significantly negatively associated with wetlands that showed evidence of a seasonal water regime $\left(\chi^{2}=11.54\right.$, $\mathrm{df}=1, P<0.001)$. While the presence of flowing water was positively associated with black rail occupancy, the average surface area covered by flowing water at wetlands with black rails was only $7 \%$, while standing water covered $16 \%$, saturated mud $27 \%$, firm mud $15 \%$ and dry substrate $34 \%$, based on the random -point data collected in 2008. Water depth at PEM1 wetlands with black rails averaged $0.83 \pm 0.15$ inch $(2.12 \pm$ 0.39 centimeters).

Black rails occupied wetlands dominated by a variety of vegetation types and were positively associated with dense cover. Sites with black rails had a
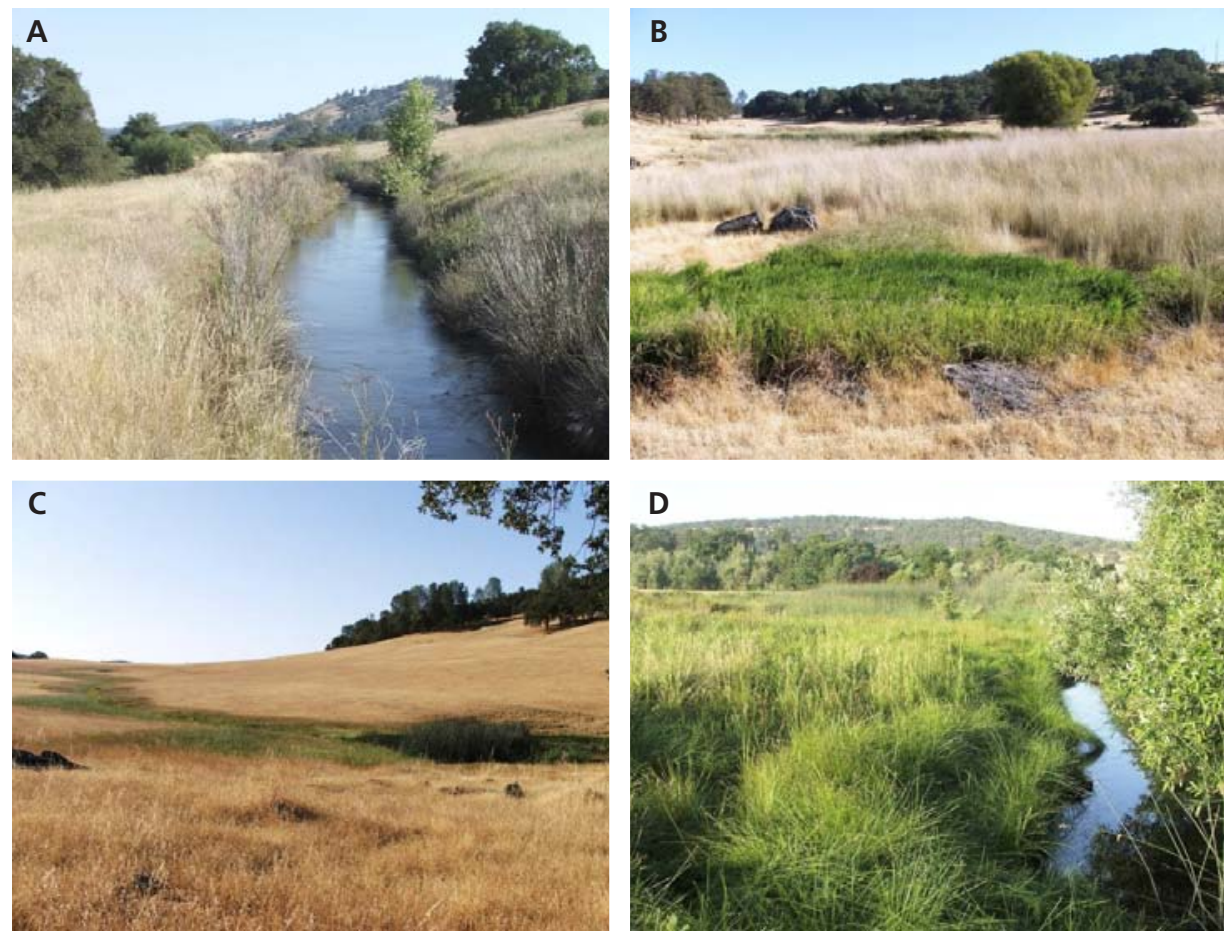

PEM1 wetlands obtain water from a variety of sources in the northern Sierra foothills including: (A) irrigation canals, (B) natural springs, (C) wetlands fed only by rainfall and (D) streams; irrigation canals are the most common source. 


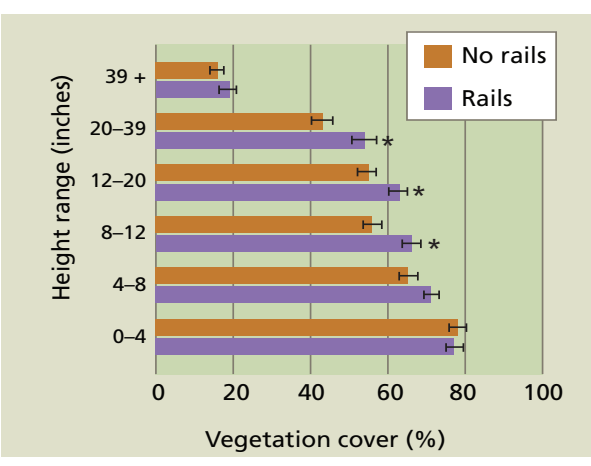

Fig. 3. Differences in vegetation cover, measured as the average percentage of random sample points with vegetation present, at six different height strata in wetlands of the northern Sierra foothills with and without black rails in 2008. Error bars represent standard errors. * Significant difference, permutation test, $P<0.05$.

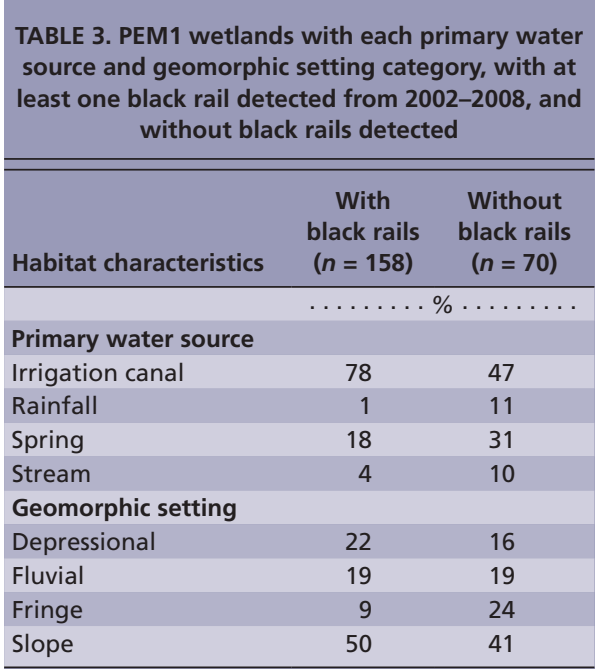

TABLE 4. PEM1 wetlands with each wettest hydrology rating category and average percentage of sample points within a wetland for each vegetation group, with and without black rails detected in 2008

\begin{tabular}{lcc}
\hline \hline $\begin{array}{l}\text { Habitat } \\
\text { characteristics }\end{array}$ & $\begin{array}{c}\text { With } \\
\text { black rails } \\
(\boldsymbol{n}=68)\end{array}$ & $\begin{array}{c}\text { Without } \\
\text { black rails } \\
(\boldsymbol{n}=115)\end{array}$ \\
\hline $\begin{array}{l}\text { Wettest hydrology } \\
\text { rating }\end{array}$ & $\ldots \ldots \ldots \% \ldots \ldots \ldots$ \\
Flowing water & 86 & 60 \\
Standing water & 13 & 25 \\
Saturated mud & 1 & 2 \\
Firm mud & 0 & 4 \\
Dry wetland & 0 & 9 \\
Vegetation group & 13 & 12 \\
Cattails & 1 & 2 \\
Cutgrass & 5 & 6 \\
Forbs & 5 & 5 \\
Hardstem bulrush & 7 & 7 \\
Himalayan blackberry & 20 & 30 \\
Other grasses & 11 & 13 \\
Other sedges & 32 & 19 \\
Rushes & 3 & 3 \\
\hline Salix & & \\
\hline
\end{tabular}
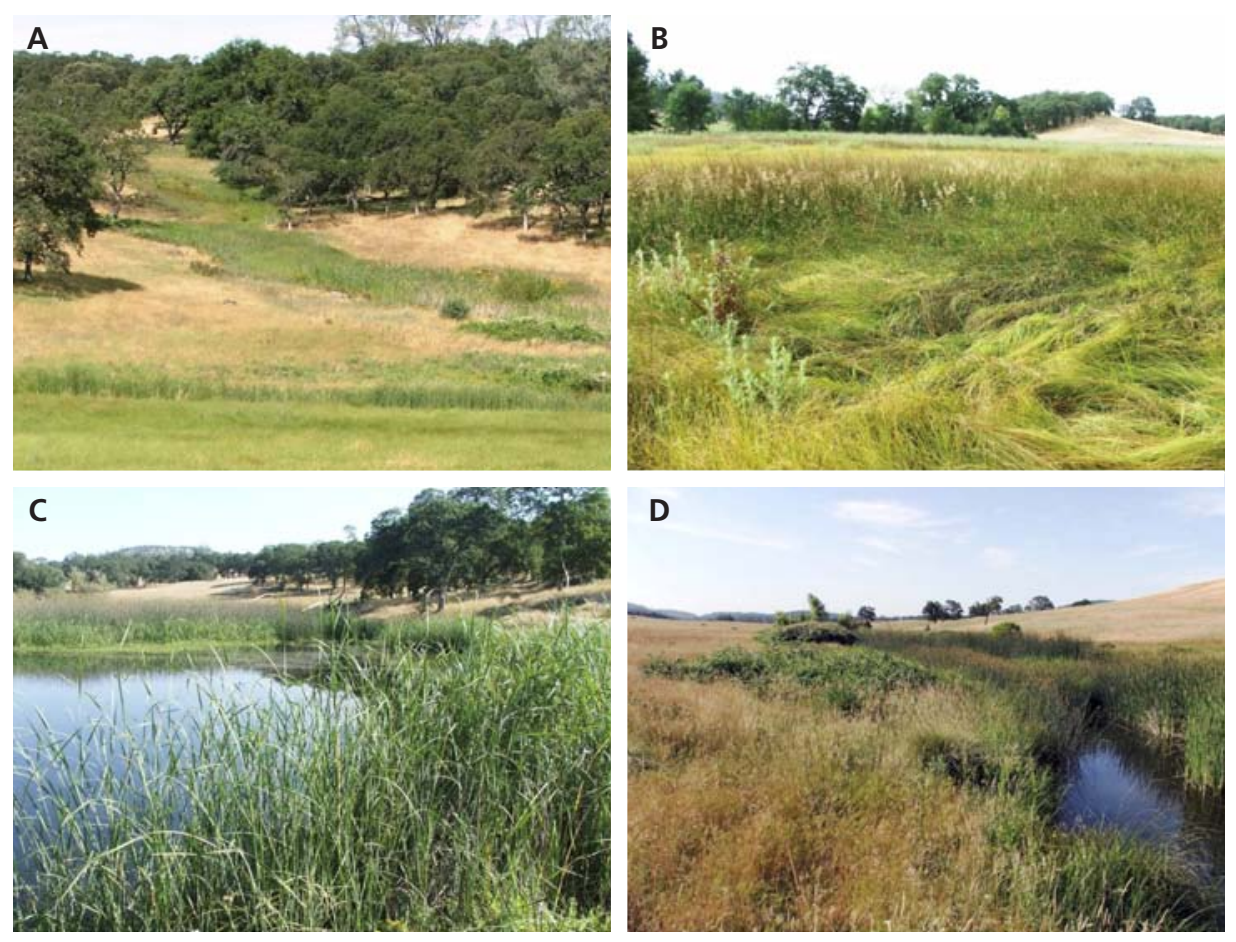

PEM1 wetlands were situated in four geomorphological settings in the northern Sierra foothills: (A) slope, (B) depressional, (C) fringe and (D) fluvial.

3.1 inches (7.9 centimeters) taller than at wetlands with no black rails $(19.5 \pm 0.8$ inches [49.6 \pm 2.0 centimeters], $n=115)$ in 2008 ( $t$-test, $P<0.01$ ) (fig. 2).

\section{Management recommendations}

Habitat loss and degradation are the primary threats to black rails (Eddleman et al. 1994), so a comprehensive black rail management strategy should focus on both site-level and landscape-level factors related to habitat. Notable site-level factors affecting occupancy by black rails include water regime, water depth, vegetation density and wetland size.

Water regime. Water regime is a critical habitat factor; black rails were most often found in wetlands with perennial standing or flowing water (permanently or semipermanently flooded), although they were occasionally found in drier wetlands with seasonally flooded, intermittently exposed or saturated water regimes (Cowardin et al. 1979). Previous studies have highlighted the importance of stable water levels for inland populations (Repking and Ohmart 1977). In the Sierra foothills, irrigation water and perennial springs and streams provide consistent permanent or semipermanent water sources during the driest part of the year, from mid-April until mid-October.
Wetlands that are fed primarily by rainfall or seasonal springs or streams are more likely to dry out as the summer progresses. Non-irrigation-fed wetlands had a lower proportion of flowing water present in both wetter and drier summers than irrigation-fed wetlands (table 1). The presence of flowing water in the summer is associated with black rail occupancy (table 4) and may be viewed as an indicator of wetland permanence. We recommend that PEM1 wetlands with permanently or semipermanently flooded water regimes be prioritized for conservation.

Black rails use wetland zones with shallower water than other North American rails (Eddleman et al. 1988), generally less than 1.2 inches ( 3 centimeters) (Flores and Eddleman 1995). Wetlands in the Sacramento Valley that are managed for waterfowl or rice typically lack sufficient shallow water zones, and previous surveys indicated that black rails were uncommon in these habitats (Richmond et al. 2008). Persistent shallow water conditions can be more easily maintained on gentle slopes rather than in depressions, since continual downslope drainage prevents water from pooling too deeply. The combination of abundant semipermanent water sources (irrigation canals and springs) and the gently sloped 
landscape of the northern Sierra foothills creates an ideal setting for such shallow wetlands to form. A management strategy that maintains wetland complexes with variable water levels, including shallow (less than 1.2 inches) water zones, is recommended. The creation of more extensive shallow water zones at the margins of managed wetlands on the Sacramento Valley floor should be explored.

Vegetation. Black rails depend on dense vegetative cover, so disturbances to wetland vegetation arising from deliberate clearing, burning or overgrazing by wildlife or livestock are potential threats. Previous research in Arizona found that plant species composition was not as important for black rail habitat selection as appropriate vegetation structure (high stem densities and canopy coverage) and substrate characteristics (Flores and Eddleman 1995). The manual removal or burning of emergent vegetation for improved pond access or to facilitate recreation activities (fishing, swimming, boating) could render a wetland unsuitable for black rails. While light-to-moderate grazing appears to be compatible with occupancy by black rails and can benefit wetlands by stimulating increased herbaceous plant productivity and improving water quality (Allen-Diaz et al. 2004; Jackson et al. 2006), our anecdotal observations suggest that black rail occupancy declines when overgrazing substantially reduces wetland vegetation cover. We recommend that landowners control livestock access to ponds and wetlands and avoid wetland vegetation removal or overgrazing, especially during the black rail breeding season (approximately March to July). Fortunately, wetland vegetation appears to rebound quickly, and a cleared or heavily grazed site can regain dense vegetation within a single growing season. Additional research is needed to determine the minimum vegetation cover that black rails require for successful breeding.

Wetland area. A critical question is the minimum wetland area required to support a breeding pair. We found that wetlands with at least one black rail detection were significantly larger than wetlands with no detections (median area 1.6 versus 0.43 acres, respectively), and $97 \%$ of wetlands with at least one
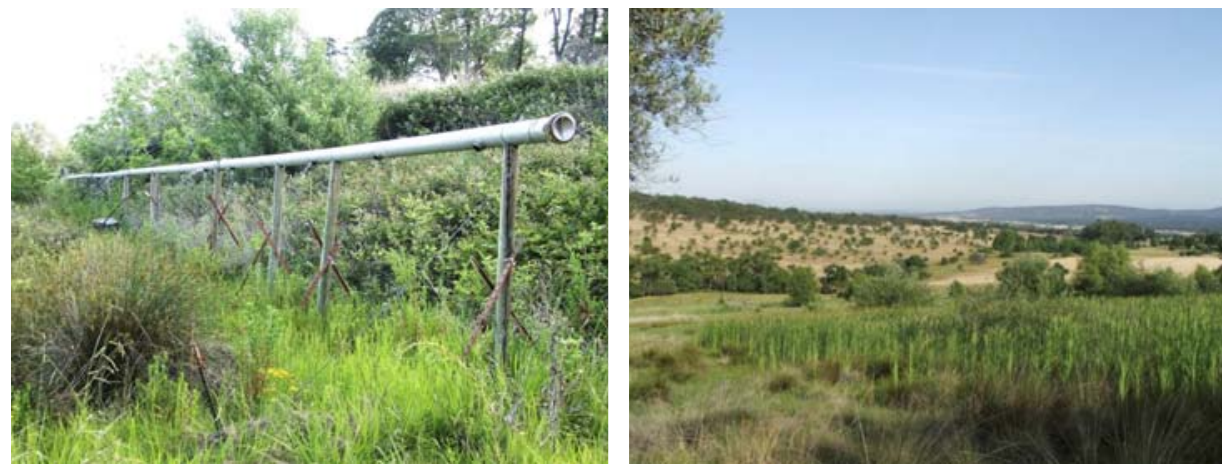

An artificial wetland created using irrigation water provides habitat for black rails at Spenceville Wildlife Area.

black rail detection were 0.25 acre or larger. However, we detected black rails occupying wetlands as small as 0.040 acre (0.016 hectare), although only temporarily. Since local rail population size should increase with wetland area, conservation priority should increase with wetland size. Nevertheless, very small wetlands (less than 0.25 acre) may also act as "stepping stones" that could facilitate dispersal across the landscape (Gibbs 1993; Loehle 2007), even if they may be too small to support breeding pairs. Based on current knowledge, we recommend that existing PEM1 wetlands with suitable water regimes and shallow water zones, especially those 0.25 acre or larger, be prioritized for conservation.

Landscape factors. Maintaining and improving site-level habitat quality is necessary for black rail management, but a comprehensive strategy must also take into consideration landscape-level factors such as isolation, canal mainte- nance and land-use change. Given the sparse and patchy distribution of PEM1 wetland habitats across the foothills, isolation of habitat patches is a potential concern. The loss of wetlands can affect metapopulation dynamics by reducing the number or density of dispersing individuals, while simultaneously increasing dispersal distances between wetlands (Gibbs 1993). Little is known about black rail dispersal aside from a radiotelemetry study in Arizona where three black rails were recorded moving an average of $0.89 \pm 0.06$ mile [ $1.43 \pm 0.09$ kilometers], range $=0.75$ to 1.00 mile between breeding seasons (Flores and Eddleman 1991).

We have noted black rails colonizing newly created wetland sites in the foothills within one year. However, we have also found evidence that the rate of patch colonization decreases and the rate of local patch extinction increases as sites become more isolated (unpublished data). A regional management

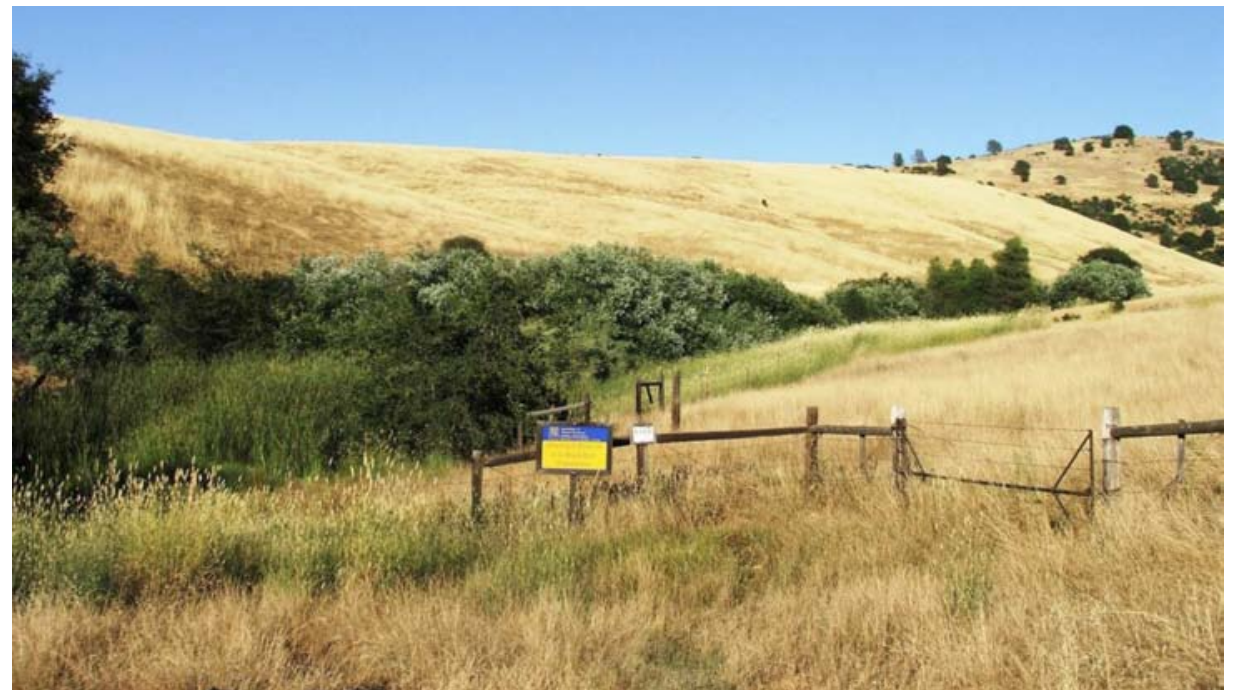

Slicks Canyon, location of the first northern Sierra foothills black rail detection, is in the UC Sierra Foothill Research and Extension Center. 
strategy for black rails should prevent the isolation of wetlands and promote the creation of new habitat to improve connectivity. In general, sites that are currently well connected should be prioritized for protection and new sites, if created, should be located close (less than 0.6 mile [ 1 kilometer]) to other occupied sites to maximize potential dispersal opportunities. Wildlife managers have successfully created several artificial wetlands - now used by black rails - by maintaining semipermanent flows of irrigation water on sloped land at Spenceville and Daugherty Hill wildlife areas. The speed with which suitable habitat can be created and then colonized by rails suggests that mitigation for wetland habitat loss from, for example, canal lining projects, may be effective. The lining of irrigation canals to improve water efficiency can adversely affect black rail habitat (Evens et al. 1991); a balanced approach to such projects should simultaneously address water efficiency and wildlife habitat needs, perhaps through a rotating short-term water-leasing program (Peck et al. 2004).

The ongoing replacement of ranching with residential land uses in the Sierra foothills (Smethurst 1999) is probably the greatest long-term threat to black rails because most of their habitat is maintained by irrigation water used for cattle ranching. PEM1 wetlands not only provide habitat for black rails, but also support wildlife species by improving tailwater quality from irrigated pastures thereby reducing loads of total suspended sediments, nitrate and Escherichia coli (Knox et al. 2008). Long-term protection of wetlands can be achieved through conservation easements and voluntary programs such as the Wetlands Reserve Program and Conservation Reserve Program run by the U.S. Department of Agriculture's Natural Resources Conservation Service, which provide landowners with opportunities to protect, restore and enhance wetlands in exchange for technical and financial support. The Central Valley Joint Venture is another important organization that brings together conservation organizations, public agencies and private landowners to conserve bird habitat in California's Central Valley. We recommend that detailed

\section{References}

Aigner PA, Tecklin J, Koehler CE. 1995. Probable breeding population of the black rail in Yuba County, California. West Bird 26:157-60.

Allen-Diaz B, Jackson RB, Bartolome JW, et al. 2004 Long-term grazing study in spring-fed wetlands reveals management tradeoffs. Cal Ag 58:144-8.

Calflora. 2010. Information on California plants for education, research and conservation. The Calflora Database, Berkeley, California (accessed Feb. 16, 2010).

[CDFG] California Department of Fish and Game. 2008. State and federally listed endangered and threatened animals of California. Sacramento, CA. www.dfg.ca.gov/biogeodata/cnddb/plants_and_animals.asp.

Conway CJ, Sulzman C. 2007. Status and habitat use of the California black rail in the southwestern USA. Wetland 27:987-8.

Cowardin LM, Carter V, Golet FC, LaRoe ET. 1979 Classification of wetlands and deepwater habitats of the United States. US Fish and Wildlife Service,

Washington, DC. Northern Prairie Wildlife Research Center Home Page, Jamestown, ND.

Eddleman WR, Flores RE, Legare M. 1994. Black rai (Laterallus jamaicensis). In: Poole A. (ed.). The Birds of North America Online. Cornell Lab of Ornithology, Ithaca, NY. http://bna.birds.cornell.edu/bna/ species/123. doi:10.2173/bna.123

Eddleman WR, Knopf FL, Meanley B, et al. 1988. Conservation of North American rallids. Wilson Bull 100:458-75.

Evens JG, Page GW, Laymon SA, Stallcup RW. 1991 Distribution, relative abundance and status of the California black rail in western North America. Condor 93:952-66

Flores RE, Eddleman WR.1991. Ecology of the California black rail in southwestern Arizona. Final Report. US Bureau of Reclamation, Yuma Project Office and Arizona Dept. of Game and Fish, Yuma, AZ.
Flores RE, Eddleman WR. 1995. California black rail use of habitat in southwestern Arizona. J Wild Manag 59:357-63.

Gibbs JP. 1993. Importance of small wetlands for the persistence of local populations of wetland-associated animals. Wetland 13:25-31.

Jackson RD, Allen-Diaz B, Oates LG, Tate KW. 2006 Spring-water nitrate increased with removal of livestock grazing in a California oak savanna. Ecosystem 9:254-67.

Knox AK, Dahlgren RA, Tate KW, Atwill ER. 2008. Efficacy of natural wetlands to retain nutrient, sediment and microbial pollutants. J Env Qual 37:1837-46.

Lewis D, Singer MJ, Dahlgren RA, Tate KW. 2000. Hydrology in a California oak woodland watershed: A 17-year study. J Hydrol 240:106-17

Loehle C. 2007. Effect of ephemeral stepping stones on metapopulations on fragmented landscapes. Ecol Complex 4:42-7.

Peck DE, McLeod DM, Hewlett JP, Lovvorn JR. 2004 Irrigation-dependent wetlands versus instream flow enhancement: Economics of water transfers from agriculture to wildlife uses. Wetlands 34:842-55.

R Development Core Team 2008. R: A Language and Environment for Statistical Computing. R Foundation for Statistical Computing, Vienna, Austria.

Repking CF, Ohmart RD. 1977. Distribution and density of black rail populations along the lower Colorado River. Condor 79:486-9.

Richmond OM, Tecklin J, Beissinger SR. 2008. Distribution of California black rails in the Sierra Nevada foothills. J Field Ornithol 79:381-90.

Smethurst D. 1999. Land degradation and the decline of ranching in the Sierra Nevada foothills, California. Land Degrad Dev 10:161-75.

[USFWS] US Fish and Wildlife Service. 1988. National list of vascular plant species that occur in wetlands. Biological Report 88 (26.9) management guidelines for black rails be integrated into existing conservation programs. Finally, impacts to black rails and other wetland-dependent species should be considered in the environmental review process for development projects that eliminate ranching lands or reduce irrigation water flows.

O.M.W. Richmond is Graduate Student, Department of Environmental Science, Policy and Management (ESPM), UC Berkeley; S.K. Chen is Marsh and Avian Biologist, Olofson Environmental, Berkeley, CA (formerly Undergraduate Student, UC Berkeley); B.B. Risk was Graduate Student, ESPM, UC Berkeley; J. Tecklin is Environmental Science Technician, UC Sierra Foothill Research and Extension Center; and S.R. Beissinger is Professor, ESPM, UC Berkeley.

We thank the UC Davis Wildlife Health Center, California Department of Fish and Game (CDFG) Resource Assessment Program, Integrated Hard- wood Range Management Program, Sacramento Audubon Society, Sierra Foothills Audubon Society, American Ornithologists' Union, Garden Club of America, American Museum of Natural History, California Agricultural Experiment Station and A. Starker Leopold Chair for funding. Thanks to John Eppley, Wei Chen Hsu, Lyla Hunt, Elizabeth Hunter, Robbie Kohley, Jora Rehm-Lorber, April Robinson and Doug Schaefer for field assistance. We are especially grateful to Armand Gonzalez and the late Barry Garrison of CDFG for their support of our work and assistance with transportation. We thank Tim Caldwell at Spenceville Wildlife Area; Dale Whitmore at Daugherty Hill Wildlife Area; Kirsten Christopherson, John Drew and Chuck Harrison for facilitating access and providing logistical support; and the staff at the UC Sierra Foothill Research and Extension Center, especially Art Craigmill, Chris Feddersen, Dustin Flavell and Doug McCreary, for logistical support; and Lawrence Janeway of the California State University (Chico) Herbarium, who helped identify plant species. Finally, we thank the many private landowners who generously granted access to conduct our surveys. 